\title{
Penafsiran Kata Syaythan Menurut Dawam Rahardjo dalam Ensiklopedi Al-Qur'an
}

Sartika Suryadinata

Universitas Islam Negeri Sunan

Kalijaga Yogyakarta

D.I Yogyakarta, Indonesia

E-mail:

sartikasuryadinata4@gmail.com

Abstrak: Tulisan ini akan membahas mengenai M. Dawam Rahardjo dan pemikirannya terhadap tafsir Al-Qur'an serta karya Ensiklopedi Al-Qur'an Tafsir Sosial Berdasarkan Konsep-konsep Kunci terutama terhadap salah satu kata kunci yaitu syaithan. Metode yang dipakai dalam penelitian ini adalah kajian Pustaka. Pembahasannya dimulai dari menguak kisah hidup seorang Dawam Rahardjo, pembahasan mengenai bukunya, dan pemikiran serta pandangannya terhadap penafsiran Al-Qur'an. Terakhir, di ujung pembahasan akan diuraikan mengenai analisa penulis mengenai penafsiran kata syaithan oleh Dawam yang telah diuraikan sebelumnya.

\begin{abstract}
This paper will discuss about M. Dawam Rahardjo and his thoughts on the interpretation of the Al-Qur'an as well as the work of the Encyclopaedia of the Al-Qur'an Social Interpretation Based on Key Concepts, especially on one of the key words, syaithan. The discussion starts with revealing the life story of Dawam Rahardjo, about Dawam Rahardjo's thoughts and views on the interpretation of the Qur'an. Finally, at the end of the discussion will be explained about the author's analysis of the interpretation of the word syaithan by Dawam that has been described previously.
\end{abstract}

Kata Kunci: Dawam Rahardjo, Syaithan, Studi, Tafsir

\section{PENDAHULUAN}

Adanya ungkapan "al-Qur'an sholihun li kulli zaman wa makan" (alQur'an sesuai dengan waktu dan tempat) sehingga tidak menutup kemungkinan untuk adanya perubahanperubahan dari penafsiran terhadap alQur'an, agar dapat menyesuaikan dengan keadaan situasi kondisi masyarakat pada zaman tersebut. Banyak ulama-ulama yang telah menulis kitab tafsir berjilid-jilid guna memudahkan umat muslim untuk memahami Al-Qur'an. Dengan menggunakan metode dan corak yang beragam, mulai dari tafsir klasik sampai kepada tafsir pada era kontemporer ini. Upaya-upaya pemahaman terhadap AlQur'an yang kemudian melahirkan karya tafsir ini telah menjadi fenomena yang umum dikalangan masyarakat Islam.

Penafsiran terhadap Al-Qur'an akan selalu terbuka bagi siapa saja yang memenuhi syarat dan mampu dalam melakukannya. Tidak menutup kemungkinan bagi umat Islam dari daerah manapun, termasuk Indonesia. Pada era kontemporer ini telah banyak bermunculan karya-karya tafsir yang 
menggunakan bahasa Indonesia yang dibuat oleh cendekiawan-cendekiawan muslim Indonesia. Guna memudahkan bagi umat Islam disetiap kalangan dalam berinteraksi dengan Al-Qur'an. Banyak dari para mufassir-mufassir pada era modern ini yang terus mengembangkan penafsiran dan menemukan ide-ide baru dalam dunia penafsiran. Bahkan banyak dari cendekiawan muslim yang latar belakang keilmuannya bukan dari ilmu tafsir, bahkan bukan keilmuan agama yang juga telah mengambil andil dalam penafsiran Al-Qur'an.

Seperti halnya M. Dawam Rahardjo yang merupakan seorang sarjana ekonomi dan imu sosial, mencoba masuk kedalam khazanah penafsiran Al-Qur'an dengan membuat sebuah karya tafsir Al-Qur'an yang diberi judul Ensiklopedi Al-Qur'an Tafsir Sosial Berdasarkan Konsep-konsep Kunci. Dengan menggunakan metode alQur'an menjelaskan satu sama lainnya, terbitlah sebuah tafsir yang kemudian ia sebut sebagai ensiklopedi al-Qur'an. Diterbitkan sebagai buku pada tahun 1996, jauh sebelum itu ternyata tulisantulisannya dalam ensiklopedi ini telah diterbitkan pada Jurnal Ulumul Qur'an.
Membuat sebuah karya dengan membahas mengenail al-Qur'an tentu akan mendapat tanggapan daripada pakar-pakar al-Qur'an lainnya, baik berupa kritikan ataupun dukungan terhadap karyanya.

\section{METODE PENELITIAN}

Dalam penelitian ini penulis menggunakan jenis penelitian kajian kepustakaan atau library research dengan menggunakan analisis deskriptif sebagai pisau analisisnya. Dan juga menggunakan metode tafsir tematik/maudhu'i yang mana topic pembahasannya mengenai penafsiran kata syaythan enurut Dawam Rahardjo. Sumber data primer dalam penelitian ini adalah ayat-ayat Al-Qur'an yang berkaitan dengan kata syaiythan yang dicantumkan dalam kitab tafsir karangan Dawam Rahardjo. Sedangkan sumber data sekundernya berasal dari buku-buku, artikel dan jurnal maupun tulisan yang berkaitan dengan topic pembahasan penelitian.

\section{HASIL DAN PEMBAHASAN}

\section{Biografi Dawam Rahardjo}

Dawam Rahardjo merupakan seorang cendekiawan muslim yang sudah tidak asing lagi dalam khazanah 
pemikiran Islam Indonesia. Beliau Kemudian melanjutkannya di SMA dilahirkan di kampung Baluwati Solo Manahan hingga lulus pada tahun 1961. pada tanggal 20 April 1942 (M. Dawam (Ihsan Ali Fauzi, 2007: 5-6). Setelah Rahardjo, 1993: 6) Dawam merupakan menyelesaikan pendidikan SMAnya anak sulung dari 8 bersaudara, ayahnya Dawam Rahardjo mendapat kesempatan bernama Muhammad Zuhdi Rahardjo untuk mengikuti AFS (American Field dan ibunya bernama Muthmainnah. Service) dan berhasil menjadi murid di Keduanya merupakan guru dan sangat Borac High School, di Idaho Amerika mementingkan pendidikan. Oleh karena Serikat selama satu tahun lamanya. itu Dawam Raharjdo menjadi anak yang Kemudian ia melanjutkan dengan rajin dan tekun dalam menuntut ilmu. kuliah di Fakultas Ekonomi Universitas Berasal dari keluarga yang sederhana, Gajah Mada dan lulus pada tahun 1969. hal itu tidak menjadi halangan baginya (M. Dawam Rahardjo, 1999: 10). untuk terus menimba ilmu. Ia banyak Karena pribadi Dawam yang haus akan mempelajari ilmu-ilmu agama, seperti ilmu serta kecintaan yang mendalam mengaji, menghafal bebrapa surat terhadap ilmu, pada tahun 2000 ia dalam Juz 'Amma. Dawam pun juga meraih gelar Doktor H.C. dalam bidang mendalami dasar-dasar pendidikan ekonomi dari Institute Agama Islam agama seperti bahasa Arab, Tafsir, Fiqh Negeri Syarif Hidayatullah Jakarta. dan hadits. Selain itu beliau juga pernah Dawam Rahardjo menikah dua kali, istri belajar ilmu tajwid di Pesantren pertamanya bernama Zainun Hawariyah Krapyak selama satu bulan lamanya. meninggal pada Desember tahun 1994. (Ihsan Ali Fauzi, 2007: 4). Akan tetapi, Dari pernikahan pertamanya ini ia menurutnya ia lebih banyak belajar memiliki 2 orang anak. Sedang istrinya sendiri melalui buku-buku bahasa Arab yang dibelinya di toko buku pada kala itu. (Saiful, 2008: 219).

Pendidikan bagi Dawam sangatlah penting, setelah lulus dari sekolah rakyat ia melanjutkan pendidikannya di yang kedua bernama Sumarni yang dinikahinya pada Maret 1995, seorang sarjana Ekonomi Universitas Islam Indonesia (UII) dan mendapat gelar MPA dari University of California (M. Dawam Rahardjo, 1996: 8). SMP 1 Solo dan lulus pada tahun 1957. 
Dawam Rahardjo sangat gemar membaca buku serta menulis, oleh karena itu tidak mengherankan lagi karna kegemarannya itu telah banyak buku-buku serta artikel-artikel yang ditulis olehnya. Bahkan Dawam pernah menjadi penulis tetap untuk Koran Mercusuar, Yogyakarta yang terbit setiap hari selasa. Setelah itu Dawam mulai dikenal luas melalui tulisantulisannya tersebut (Ihsan Ali Fauzi, 2009: 10).

Perjalanan karir Dawam Rahardjo dimulai dengan bekerja sebagai Staf di Departemen Kredit Bank of America di Jakarta, namun setelah 2 tahun bekerja beliau memilih berhenti yang kemudian ia bergabung di LP3ES (Lembaga Penelitian dan Pembangunan EkonomiSosial) sebagai staf peneliti. LP3ES berperan besar dalam menambah pengetahuan Dawam Rahardjo dalam segi ekonomi kerakyatan. Ia semakin gencar menulis mengenai ekonomi kerakyatan dan banyak telah banyak dimuat di media massa (Adnan, 2010: 280). Selama kurang lebih 10 tahun bekerja di LP3ES membuat Dawam jatuh cinta dengan Lembaga Swadaya Masyarakat (LSM). Hal ini dapat dibuktikan dengan perannya sebagai pemimpin dari beberapa LSM, seperti: Lembaga Studi Ilmu-Ilmu Kemasyarakatan, Lembaga Studi Pembangunan, Pusat Pengembangan Masyarakat Agrikarya (PPMA), dan Lembaga Studi Agama dan Filsafat (Dawam Rahardjo, 1996: 2).

Pada tahun 1993, Dawam Rahardjo mengemban dua amanah sekaligus, yaitu sebagai Guru Besar Ekonomi Pembangunan di Universitas Muhammadiyah Malang dan menjadi Rektor Universitas Islam 45 (UNISMA) Bekasi. Sebelum itu ia juga diminta untuk menjadi dosen di Program Pasca Sarjana UII serta membina Program Studi Ekonomi Islam di IAIN Syarif Hidayatullah. Dan lagi, pada tahun 1999 Dawam ditunjuk sebagai Presiden Director The International Institute Of Islamic Thought Indonesia (IIIT Indonesia). Karena keberhasilan dan prestasinya Dawam Rahardjo menerima tanda jasa, diantaranya sebagai berikut: Tanda Kehormatan Bintang Maha Putra (1999), Penghargaan Tertinggi DEKOPIN: "Hatta Nugraha" (1997), serta penghargaan Bintang Satya Pembangunan dari Presiden RI pada tahun 1995 (Ihsan Ali Fauzi, 2009: 10). 
Kesibukan Dawam setiap harinya, Pembangunan Ekonomi, (Ihsan Ali tidak menjadi halangan baginya untuk Fauzi: 16). Kemudian, diantara mengemban jabatan penting di dalam karyanya dalam bidang Al-Quran dan luar organsasi. Ia pernah adalah: Paradigma Al-Qur'an: menduduki jabatan sebagai Ketua Metodologi Tafsir dan Kritik Sosial, Dewan Pakar ICMI (Ikatan Ensklopedi Al-Qur'an: Tafsir Sosial Cendekiawan Muslim Indonesia), Berdasarkan Konsep-Konsep Kunci.

Direktur Utama Pusat Pengembangan Agribisnis, pemimpin Jurnal Ilmu dan Sekilas Tentang Ensiklopedia AlQur'an

Tidak dapat dipungkiri bahwa Kebudayaan Ulumul Qur'an, Ketua Dewan Direktur Studi Agama dan Filsafat, dan Dosen di Lembaga Pengembangan dan Pendidikan Manajemen di Jakarta (Dawam Rahardjo: 7).

Jika dilihat secara formal, Dawam Rahardjo adalah seorang akademi ekonomi, namun pengetahuan dan karya-karya ilmiahnya tidak terbatas pada satu disiplin ilmu saja, melainkan beberapa disiplin ilmu dimulai dari bidang ekonomi, sosial, politik, filsafat dan agama. Adapun beberapa karyakarya M. Dawam Rahardjo tersebut adalah: Etika Manajemen dan Ekonomi, Transformasi Pertanian, Industrialisasi dan Kesempatan Kerja, Bank Indonesia dalam Kilasan Sejarah Bangsa, Pragmatisme dan Utopia, Corak Dawam Rahardjo lebih dikenal sebagai seorang pakar ekonomi daripada seorang mufassir. Menurutnya, sedari kecil ia sudah sangat akrab dengan AlQur'an dan memiliki kemampuan yang cukup untuk memahaminya. Perkenalannya dengan tafsir dimulai saat ia masih tingkat SMP. Beliau mulai membaca tafsir Kandungan Al-Fatihah karya Bahrum Rangkuti membuatnya merasa tertarik dengan tafsir Al-Qur'an. Barulah kemudian ia mulai membaca Tafsir al-Azhar karya Hamka, Qur'an Suci karya Muhammad Ali yang kemudian diterjemahkan menjadi The Holy Qur'an oleh Kol. Moh. Bachrun, serta tafsir karya Mahmud Yunus (Wardani, 2017: 17).

Dawam ibarat menorobos batas Nasionalisme Indonesia, Habibi dalam menulis Ensiklopedia Al-Qur'an, Economics: Telaah Pemikiran Tafsir Sosial Berdasarkan Konsep 
Kunci-kunci ini. Dikatakan demikian karena, ia belum memiliki persyaratan sebagai mufassir yang dituntut benarbenar mengusai ilmu-ilmu tafsir, seperti yang diyakini oleh kebanyakan ulama (Saiful Amin Ghafur: 227). Meskipun berlatar belakang sebagai seorang pakar ekonomi, tidak menyurutkan perhatian dan semangatnya dalam penafsiran. Buku ini, pada mulanya berasal dari artikel-artikel yang ditulisnya dalam jurnal Ulumul Qur'an yang dipimpinnya ketika itu. Menurutnya, Al-Qur'an merupakan petunjuk bagi keseluruhan umat manusia, oleh karena itu setiap manusia memiliki potensi untuk memperoleh petunjuk itu. Baik melalui penafsirannya sendiri, maupun merujuk pada penafsiran orang lain (Dawam Rahardjo: 3).

Buku Ensiklopedia Al-Qur'an ini terdiri dari 764 halaman, dan hanya memiliki 1 jilid saja yang dilengkapi dengan indeks pada halaman terakhirnya. Dalam melakukan penafsiran, Dawam lebih cenderung menggunakan metode maudhu'i. Dengan membagi pembahasan menjadi 27 kata kunci yaitu dimulai dengan menjelaskan kata fithrah sampai pada pembahasan terakhir mengenai amar ma'ruf nahi mungkar. Dalam menafsirkan ayat Al-Qur'an, umumnya seorang mufassir harus menguasai bahasa Arab dan seluk beluknya. Dawam paham betul akan kekurangannya tersebut. Oleh karena itu, ia berguru kepada Ahmad Rifa'i Hasan untuk menanyakan hal-hal yang berkaitan dengan bahasa Arab serta mengenai seluk beluk Al-Qur'an. Menurutnya salah satu keistimewaan Al-Qur'an adalah dapat memberi petunjuk kepada setiap orang sepertinya yang tidak dapat disebut sebagai mufassir sama sekali, meskipun tidak melalui pendidikan formal (Dawam Rahardjo: xxi)

Sebuah buku tafsir Al-Qur'an tidak selalu harus mencakup keseluruhan AlQur'an. Berupa karangan-karangan pendek saja sudah bisa dijadikan tafsir Al-Qur'an, menurut pendapatnya. Dengan pendapatnya ini kemudian Dawam menulis tafsir Al-Qur'an dengan memilih tema-tema yang disesuaikannya dengan keilmuan yang dimilikinya. Sehingga, kajian AlQur'an dapat dipahami oleh semua orang sesuai dengan keahliannya masing-masing. Dengan demikian setiap orang dari berbagai kalangan dan 
tingkatan dapat berinteraksi langsung dengan Al-Qur'an, terutama rakyat Indonesia. Itulah kenginan terbersarnya dan kemudian menjadi alasannya untuk menulis buku Ensiklopedia Al-Qur'an, Tafsir Sosial Berdasarkan Konsepkonsep Kunci (Saiful Amin Ghafur: 222).

Dawam Rahardjo berpendapat bahwa para ulama tafsir, pemimpin dan cendekiawan muslim tidak mampu mengembangkan konsep-konsep agama Islam dalam menjawab tantangan zaman. Serta kurangnya upaya untuk memecahkan masalah ilmu tafsir, sehingga ilmu ini kurang berkembang dan kurang diminati untuk ditekuni (Dawam Rahardjo: xxi). Dalam karya tafsirnya ini referensi yang digunakan olehnya kebanyakan berbahasa Indoenesia dan beberapa berbahasa Inggris. Sangat jarang sekali ia mengutip dari sumber yang berbahasa Arab. Adapun beberapa sumber berbahasa yang ia kutip, semuanya adalah edisi terjemahan. Ini dikarenakan kurangnya penguasaan Dawam terhadap bahasa Arab. Tidak hanya AlQur'an ia juga mengambil hadis Nabi sebagai rujukan, serta kitab suci agama lain.
Dalam menafsirkan, Dawam juga sering merujuk kepada pendapat para mufassir serta ilmu lainnya. Mufassir yang menjadi rujukannya diantaranya ialah: Hamka (Tafsir al-Azhar), Hasbi Ash-Shiddqiey (Tafsir al-Bayan), M. Abduh dan Rasyid Ridha (Tafsir alManar), Mahmud Syaltut (Tafsir AlQur'an al-Karim), Maulana Muhammad Ali (The Holy Qur'an), Fazulur Rahman (Major Themes Of The Qur'an, dan lain-lain. (Dawam Rahardjo: 77)

\section{Tafsir Al-Qur'an dalam Sudut Pandang Dawam Rahardjo}

Dawam Rahardjo yang bukan lulusan sarjana tafsir memiliki semangat dan kepercayaan diri yang besar dalam menafsirkan Al-Qur'an. Namun, kajian tafsir di era kontemporer ini telah banyak sarjana non agama yang mengambil posisi guna mengembangkan kajian tafsir. Dawam menafsirkan Al-Qur'an sesuai dengan keilmuan yang dikuasainya. Dalam menafsirkan Al-Qur'an sangat terlihat sekali pengaruh disiplin ilmu yang dimilikinya dan lebih condong kepada sosial kemasyarakatan.

Ulama tafsir telah menetapkan adanya syarat-syarat untuk menjadi 
seorang mufassir. Seperti yang Dawam itu hanya akan menghambat dikemukakan oleh Syaikh Manna' al- usaha para pembaharu dan cendekiawan Qathan diantaranya: 1. Berakidah benar, muslim yang ingin mengambil andil 2. Bersih dari hawa nafsu, 3. Dalam untuk menafsirkan Al-Qur'an. Menurut menafsirkan harus mendahulukan Dawam penafsiran Al-Qur'an bukan tafsiran al-Qur'an dengan al-Qur'an, hanya sekedar metodologi saja kemudian sunnah, perkataan sahabat, melainkan sikap hati dan sikap berserah dan jika tidak diperoleh baru merujuk diri kepada Allah agar diberikan kepada pendapat para tabi'in, 4. petunjuk (Dawam Rahardjo: 2).

Berpengetahuan Arab yang baik, 5. Tafsir menurut Dawam ialah Berpengetahuan tentang prinsip-prinsip mengungkapkan maksud dan petunjuk ilmu yang berkaitan dengan Al-Qur'an, al-Qur'an yang masih umum. Oleh dan 6. Memiliki pemahaman yang karena itu membutuhkan penjelasan cermat (Syaikh Manna al-Qathan, 2008: yang lebih lanjut, dan al-Qur'an 414-417). menurutnya saling menjelaskan satu

Adanya ketetapan syarat-syarat sama lainnya, oleh karena itu mufassir diatas, Dawam sebagai sarjana ekonomi dan ilmu sosial sangat tidak setuju dengan sejumlah ulama tafsir yang menetapkan syarat-syarat yang sulit untuk dipenuhi, dimulai dari AlQur'an yang harus ditafsirkan secara lengkap 30 juz. Menurutnya hal demikian sangat sulit untuk dilaksanakan karena akan memakan waktu yang sangat lama. Sedangkan masyarakat sudah sangat membutuhkan tafsir Al-Qur'an, selain itu syarat-syarat lain yang menaharuskan untuk metode tafsir maudhi'i terpapar dengan menguasai ilmu nahwu sharaf, badi', jelas dalam karya Dawam Rahardjo ini. bayan, bahasa Arab dan lain-lain. Bagi Menurutnya tafsir maudhu'i itu muncul 
karena dipengaruhi perkembangan ilmu sosial budaya. Dengan mengambil contoh, pertanyaan tentang hakikat manusia, yang kemudian ditemukan jawabannya melalui ayat Al-Qur'an yang menerangkan tentang manusia. Seperti yang dilakukan oleh Abbas alAqqad dalam karyanya, al-Insan fi AlQur'an. Namun metode maudhu'i yang ditawarkan Dawam dalam tafsirnya berbeda dengan teori maudhu'i yang dikemukakan oleh al-Farmawi.

Menurut Dawam metode maudhu' $i$ itu beritik tolak pada tiga hal, yakni dari konsep ilmu sosial, dari istilah AlQur'an itu sendiri, dan dari isitilah ilmu keislaman (Dawam Rahardjo: 7).

Jika dilihat dari titik tolak yang diungkapkanya, maka penafsiran Dawam dalam Ensiklopedia Al-Qur'an ini dapat dikategorikan kedalam konsep isitlah Al-Qur'an. Karena dalam penafsirannya Dawam membagi konsep kuncinya kedalam 27 tema yang mana tema-tema tersebut berasal dari istilahistilah dalam Al-Qur'an. Dan lagi 27 istilah-istilah yang diambil Dawam ini sudah sangat akrab digunakan dalam bahasa masyarakat Islam. Dalam penafsirannya sering kali ia mengaitkannya dengan realita yang terjadi di tengah masyarakat saat itu. Kadang pula, ia mencamtumkan sejarah-sejarah dengan mengaitkannya kembali pada realita kehidupan masyarakat Indonesia. Oleh karena itu, dapat dikatakan bahwa tafsir Dawam ini menggunakan corak adabi ijtima'i dalam penafsirannya.

Dawam beranggapan bahwa AlQur'an itu merupakan ensiklopedi yang unik dan isitimewa. Dikatakannya demikian karena seperti kita menanyakan berbagai istilah misalnya, arti taqwa atau ikhlash maka ayat-ayat Al-Qur'an yang akan memberi jawaban, melalu proses dan pengahayatan yang dilakukan secara terus menerus. Maka seharusnya seorang muslim itu selalu hidup berdampingan dengan Al-Qur'an (Dawam Rahardjo: 17). Dawam menyajikan karya tafsirnya ini kedalam bentuk ensiklopedi, yang memaparkan tema-tema berasal dari istilah-istilah dalam Al-Qur'an, menurutnya tafsir seperti inilah yang dibutuhkan masyarakat zaman sekarang ini. Dan lagi, agar memudahkan penafsir selanjutnya untuk menafsirkan AlQur'an berdasarkan tema-tema khusus (Dawam Rahardjo: 35). 
Untuk lebih jelasnya, penulis akan memaparkan salah satu contoh penafsiran Dawam di dalam Buku Ensiklopedi Al-Qur'an, Tafsir Sosial Berdasrkan Konsep-konsep Kunci, dengan mengambil tema syaythan. Dalam memulai penafsirannya tentang suatu tema, Dawam menyajikannya dengan cara membaginya ke dalam beberapa sub tema, tema syaythan ini yang kemudian dibagi menjadi 3 sub tema, yaitu Agama dan Mitologi Setan, Mitologi tentang Ular, dan Syaythan dalam Al-Qur'an.

\section{Syaythan}

Setan atau satan adalah istilah yang sudah akrab di tengah masyarakat tidak hanya di kalangan muslim, akan tetapi juga dikenal dalam agama-agama Yahudi dan Kristen. Di dalam AlQur'an terdapat kata syaythan dan iblis, yang mana keduanya mengandung makna yang sama yaitu makhluk dan kekuatan jahat. Inilah yang nanti akan diuraikan, mencakup kepada pengertiannya, pengenalan di dalam agama lain dengan nama yang berbeda, serta mitologi-mitologi kuno ataupun modern yang terkenal di masyarakat yang terkait dengannya. Dalam bahasa Inggris setan dikenal dengan nama devil atau demon yang mengandung pengertian yang sama dengan iblis dan setan (Dawam Rahardjo: 274).

\section{Agama dan Mitologi Setan}

Dalam tradisi Kristen setan adalah "kekuatan jahat yang sangat dahsyat" sedangkan dalam tradisi Israeli setan adalah musuh (Beelzebub). Jika dilihat dalam perjanjian lama setan itu digambarkan dalam bentuk ular, yang menggambarkan sesuatu yang licik, dan pandai mengelak, bagaikan binatang melata yang buas dan sangat ditakuti. Biasanya iblis atau setan dalam persepsi masyarakat kuno adalah dewa-dewa asing. Iblis itu adalah sesuatu yang ghaib, katanya setiap manusia memiliki sepuluh ribu iblis di sebelah kirinya, dan seribu iblis di sebelah kanannya. Mereka menyukai dan hidup ditempattempat terpencil dan kotor. Sehingga manusia yang suka menyendiri dan berdiam di tempat terpencil, akan terdorong untuk melakukan hal-hal negatif. Oleh karena itu seseorang yang marah dengan sangat menggebu-gebu, sering disebut dengan "kerasukan setan". Bahkan timbulnya kecemburuan pun dapat dikarenakan hasutan setan.

Dalam mitologi Yunani yang hidup dalam masyarakat Athena, Dewa 
Anggur, Dionysus, menganggap iblis sebagai malaikat-malaikat yang memberontak melawan Tuhan dan mengalami kejatuhan. Pemimpinnya adalah setan. Dan, dalam bahasa Yunani iblis disebut dengan istilah diabolos yang artinya persekutuan dengan iblis. Lain lagi halnya dalam mitologi Rumania, terdapat kepercayaan dan peribahasa-peribahasa yang menggambarkan bahwa Tuhan dan setan itu "bersaudara", sebagaimana ikatan persaudaraan antara deva dan asura dalam kepercayaan India (Dawam Rahardjo: 278).

Dawam Rahardjo mengutip pendapat Joseph Cambell, seorang ahli mitologi Amerika yang menyatakan bahwa kepercayaan Islam itu merupakan kelanjutan dari sebuah tradisi Zoroaster-Yahudi-Kristen. Islam hanya memulihkan kembali tradisi itu ke dalam pengertian yang benar dan kemudian dirumuskan secara sempurna, khususnya mengenai konsep setan dan iblis. Kemudian Dawam melanjutkan dengan pendapatnya bahwa, Islam berbeda dengan Zoroaster ataupun yang biasanya disebut dengan agama Majusi, terdapat perbedaan yang fundamental di dalamnya sehingga tidak dapat disamakan. Namun, ajaran tentang Tuhan, kekuatan roh jahat, hari kebangkitan, surga dan neraka pada ajaran Zoroaster memang mirip dengan ajaran Islam.

\section{Mitologi Ular}

Dalam tradisi Yahudi, seperti yang terdapat di dalam Perjanjian Lama bahwa setan yang membujuk Hawa adalah seekor ular. Perilaku ular yang menggoda dan merayu Hawa adalah perilaku setan yang membujuk dan menyesatkan manusia. Dalam mitologi yang hidup pada bangsa-bangsa kuno yang bahkan hingga saat ini masi dipercaya oleh sebagian orang, setan kerap kali digambarkan seperti ular. Dalam kepercayaan India kuno misalnya, keburukan-keburukan dewa disebut juga sebagai ular atau naga. Saat sekarang ini orang yang jahat dan banyak menyembunyikan perbuatan jahatnya dan melakukan keburukan, maka akan disebut sebagai ular untuk menggambarkan kejahatannya. Dalam ranah politik pun tidak jarang digunakan sebutan seperti itu. Ular adalah penggambaran untuk setan, iblis dan orang yang jahat (Dawam Rahardjo: 282). 


\section{Syaythan dalam Al-Qur'an}

Setan berasal dari kata sya-tha-nun, sebagai kata benda Syaythan, diterjemahkan oleh Hanna E. Kassis dengan satan, yang memang sudah menjadi istilah Inggris. Dalam AlQur'an kata setan disebut 88 kali dalam 35 surat. Mawlana Muhammad Ali mengatakan dalam tafsirannya terhadap surat al-Baqarah ayat 36 yang dikutip oleh Dawam menyebutkan bahwa setan adalah salah satu sebutan iblis. Hal tersebut merupakan tafsirannya terhadap ayat 34-36. Secara keseluruhan ayat tersebut berbunyi sebagai berikut: (Dawam Rahardjo: 284)

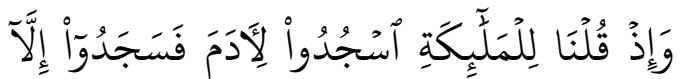

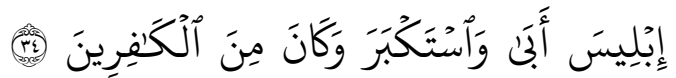

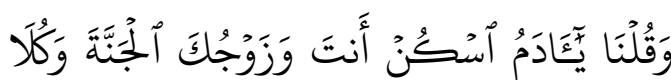

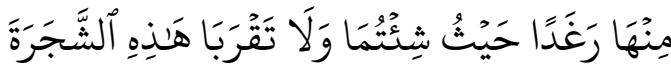

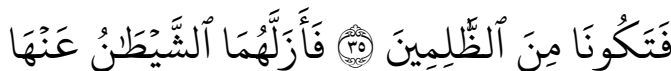

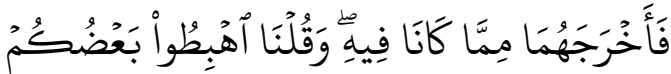

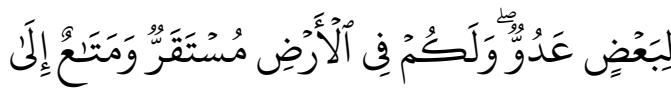<smiles>[As]#[W]</smiles>

Dan (ingatlah) ketika Kami berfirman kepada para malaikat: "Sujudlah kamu kepada Adam," maka sujudlah mereka kecuali Iblis; ia enggan dan takabur dan adalah ia termasuk golongan orang-orang yang kafir. Dan Kami berfirman: "Hai Adam, diamilah oleh kamu dan isterimu surga ini, dan makanlah makanan-makanannya yang banyak lagi baik dimana saja yang kamu sukai, dan janganlah kamu dekati pohon ini, yang menyebabkan kamu termasuk orang-orang yang zalim. Lalu keduanya digelincirkan oleh syaitan dari surga itu dan dikeluarkan dari keadaan semula dan Kami berfirman: "Turunlah kamu! sebagian kamu menjadi musuh bagi yang lain, dan bagi kamu ada tempat kediaman di bumi, dan kesenangan hidup sampai waktu yang ditentukan"

Setan juga diperuntukkan untuk menggambarkan berbagai perilaku dan peranan manusia. Tafsir The Holy Qur'an karya Muhammad Ali, menyebutkan beberapa hal tentang setan yang berbentuk manusia. Seperti yang disebutkan dalam Al-Qur'an surat Ali Imran ayat 175 sebagai berikut: (Dawam Rahardjo: 290)

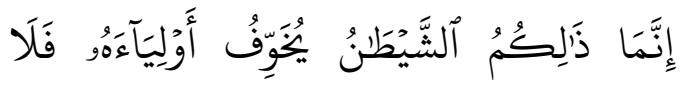

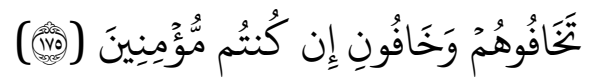

Sesungguhnya mereka itu tidak lain hanyalah syaitan yang menakut-nakuti (kamu) dengan kawan-kawannya (orang-orang musyrik Quraisy), karena itu janganlah kamu takut kepada mereka, tetapi takutlah kepada-Ku, jika kamu benar-benar orang yang beriman.

Dalam ayat tersebut setan digambarkan segai kelompok yang menakut-nakuti kamu Muslim dengan ancaman-ancamannya. Dalam ayat lain, yaitu Q.S al-Nas ayat 1-6 dijelaskan 
secara gambling bahwa setan itu, yang gejalanya dapat dilihat dari bisikan kejahatan, bisa dating dari jinn, yaitu sesuatu yang tersembunyi dan bisa pula menjelma ke dalam diri manusia:

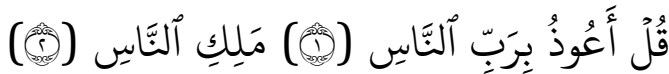

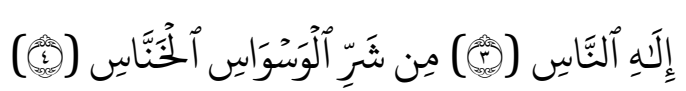

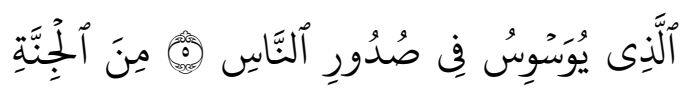

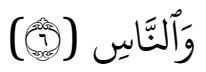

Katakanlah: "Aku berlindung kepada Tuhan (yang memelihara dan menguasai) manusia. Raja manusia. Sembahan manusia. Dari kejahatan (bisikan) syaitan yang biasa bersembunyi. Yang membisikkan (kejahatan) ke dalam dada manusia. Dari (golongan) jin dan manusia.

Dan lagi dari ayat ini dapat ditafsirkan bahwa setan itu bisa mengambil bentuk jin maupun manusia. Tergantung kepada penafsiran kita mengenai apa yang dimaksud sebagai jin itu. Karena, sering kali yang dimaksud dengan jin itu adalah manusia juga. Dikalangan masyarakat Arab, istilah jin dipakai untuk menggambarkan teman dekat atau orang yang sangat pandai. Ini tentu akan sangat berpengaruh paa penafsiran kita terhadap banyaknya penggunaan kata jin di dalam Al-Qur'an. Sebagai contoh adalah ayat tentang mu'jizat Al-Qur'an
Q.S al-Isra ayat 88: (Dawam Rahardjo: 291)
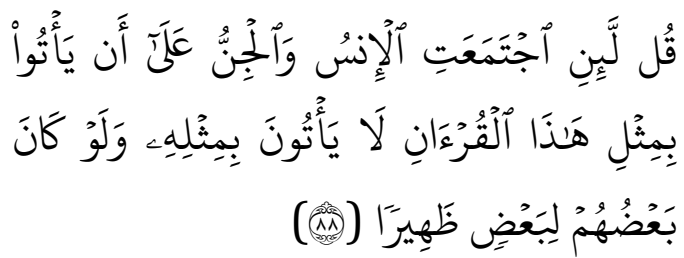

Katakanlah: "Sesungguhnya jika manusia dan jin berkumpul untuk membuat yang serupa Al Quran ini, niscaya mereka tidak akan dapat membuat yang serupa dengan dia, sekalipun sebagian mereka menjadi pembantu bagi sebagian yang lain".

Kata jin di dalam ayat diatas bisa ditafsirkan sebagai roh jahat, tetapi juga sebagai pemimpin kejahatan atau orangorang yang sangat pandai. Demikian pula halnya kata setan, bisa diartikan sebagai jin dan maupun manusia (Dawam Rahardjo: 292).

Setelah melihat salah satu contoh penafsiran Dawam Rahardjo dalam Ensiklopedi Al-Qur'an di atas, pada bagian awal sebelum masuk sub pembahasan, Dawam memberikan sedikit prolog mengenai apa yang akan dibahasnya di dalam sub-sub tema. Dapat dilihat juga Dawam sering merujuk kepada kitab-kitab agama lain, serta mengaitkannya dengan berbagai mitologi seperti mitologi Yunani, India dan Rumania. Dalam hal inipun ia sering mengutip pendapat ahli-ahli 
mitologi barat untuk menafsirkannya. Untuk menafsirkan kata syaythan ini Dawam seakan melarikan pembicaraannya kepada tema lainnya. Seperti membahas penggunaan kata ular di berbagai mitologi. Akan tetapi meskipun demikian, pada sub bab pembahasan terakhir, mengenai syaythan di dalam Al-Qur'an dalam mengupas tuntas dengan mencantumkan ayat-ayat Al-Qur'an yang berkaitan dan kemudian juga menambahkan penafsiran ulama dari kitab tafsir lainnya untuk menguatkan penafsirannya.

Dari sinilah dapat dilihat bahwa Dawam menggunakan metode maudhu'i dalam kitab tafsirnya. Meskipun sebelumnya Dawam seakan ingin berpanjang lebar membahas makna syaithan menurut pandangan agama lain, mengutip pendapatpendapat dari kitab suci agama lain, namun di ujung pembahasan ia seakan memperlihatkan bawah al-Qur'an lah yang dapat menjawab semuanya dengan sempurna. Terlihat dengan banyaknya ayat-ayat dan penafsiran para ulama dalam menyelesaikan penafsirannya terhadap sebuah kata kunci.
Tidak dapat dipungkiri bahwa backgroundnya sebagai seorang sarjana sosial begitu nampak jelas dalam penafsirannya. Sesuatu yang menarik di dalam tafsirannya setelah menyelesaikan menafsirkan sebuah kata kunci, sebelum masuk kepada kata kunci yang lainnya, Dawam akan selalu mengulas sedikit mengenai kata kunci yang akan dibahas selanjutnya. Jika dilihat balik ke atas, pemilihan Dawam untuk membahas mengenai mitologimitologi terlebih dahulu dan merujuk kepada kitab suci agama lain adalah sebagai pembandingnya atau digunakan sebagai informasi tambahan dalam menambah wawasan.

Sebagai seorang sarjana sosial Dawam membuktikan dirinya mampu untuk menghasilkan kitab tafsir dan menafsrikan al-Qur'an dengan warna dan sudut pandang yang berbeda. Meski melalui banyak kritikan pun pembelaan dari para cendekiawan-cendekiawan muslim lainnya. Dawam Rahardji ingin masyarakat Indonesia bisa meresapi dan membaca dengan penuh hikmah tulisan di dalam karyanya ini. Karena semua istilah kunci-kunci yang digunakan Dawam adalah bahasa yang sering ditemui oleh masyarakat sehari-hari, 
sehingga akan semudah dalam memahaminya.

\section{KESIMPULAN}

Dawam Rahardjo sebagai seorang sarjana ekonomi yang memiliki kepercayaan diri yang sangat tinggi dalam membuat Ensiklopedi Al-Qur'an ini. Dengan lahirnya karya Dawam di era tafsir kontemporer ini telah banyak memberikan pembaruan. Seperti halnya pandangannya terhadap syarat-syarat sebagai seorang mufassir. Ia juga memiliki ciri khas penafsirannya sendiri dengan tidak menafsirkan Al-Qur'an lengkap 30 Juz, dan lebih memilih membuatnya seperti ensiklopedi berdasarkan istilah-istilah tema yang diambil dari Al-Qur'an itu sendiri.

\section{REFERENSI}

Fauzi Ihsan Ali, 2007, et al, Demi Toleransi Demi Pluralisme, Jakarta Selatan: Paramadina

Ghofur Saiful Amin, 2008, Profil Para Mufasir Al-Qur'an, Yogyakarta: Pustaka Insan Madani

Gusmian, Islah, 2002, Khazanah Tafsir Indonesia: Dari Hermeneutika hingga Ideologi, Jakarta: Teraju.

Hafizullah, Hafizullah. "METODE PENAFSIRAN IBNU AL- 